\title{
Pembelajaran Al-Qur'an Anti Radikalisme di Kalangan Pelajar Sekolah Menengah
}

\author{
Fahmi Eko Saputro \\ Program Studi Pendidikan Agama Islam (PAI), Program Pascasarjana, IAIN Salatiga \\ Email: fahmiskripsi2@gmail.com
}

Received: June 22, 2020 | Accepted: December 2, 2020

\begin{abstract}
Radicalism is a problem of human civilization. Empirical facts show that high school-age children are very vulnerable to infecting radicalism. This is confirmed by surveys of research institutions that can be trusted. From this fact, schools / madrasas must start teaching that is able to ward off radicalism. Al-Qur'an subjects Hadith in Madrasas or Islamic religious education in secondary schools must be planned using the concept of learning anti-radicalism. One learning model that can be used is a scientific learning model. In the context of al-Qur'an material and hadith, students must be taught and introduced to study the Qur'an as a method of thinking. Thus, the understanding of the Qur'an and Hadith can be understood in its socio-historical context. Understanding related to asbab al-nuzul, makiyah-madaniyah and other analytical tools can be used so that the understanding of the Qur'an and non-intellectual traditions. This article seeks to prove that scientific learning can be used as a model of anti-radicalism learning. Learning the scientific model begins with observing, asking, gathering information, processing information, and communicating. With the steps of scientific learning in the material al-Qur'an and the hadith, allowing learning to be done by using theories of facilitation. Students can observe the cases that occur around them by observing news media online and also the understanding of the Qur'an and hadith from various sources. The information processing stage can be used so that the critical power of students towards the results of the interpretation of the Qur'an increases. Students can also discuss the results of gathering information obtained with their peers and the teacher becomes the facilitator. The conclusion that can be drawn in this study is that scientific learning can be used as a model of learning the Koran and the Hadith that has a spirit of antiradicalism.
\end{abstract}

\begin{abstract}
Abstrak
Radikalisme adalah masalah peradaban manusia. Fakta empiris menunjukkan bahwa anak usia SMA sangat rentan untuk menginfeksi radikalisme. Hal ini dikonfirmasi oleh survei lembaga penelitian yang dapat dipercaya. Dari fakta ini, sekolah/madrasah harus mulai mengajar yang mampu menangkal radikalisme. Al-Qur'an subyek hadits di Madrasah atau pendidikan agama Islam di sekolah menengah harus direncanakan dengan menggunakan konsep pembelajaran antiradikalisme. Salah satu model pembelajaran yang dapat digunakan adalah model pembelajaran ilmiah. Dalam konteks Al-Qur'an materi dan hadits, siswa harus diajarkan dan diperkenalkan untuk mempelajari Al-Qur'an sebagai metode berpikir. Dengan demikian, pemahaman AlQur'an dan Hadis dapat dimengerti dalam konteks sosial-historis. Pemahaman terkait dengan asbab an-nuzul, makiyah-madaniyah dan Alat analisa lain dapat digunakan agar pemahaman $\mathrm{Al}$
\end{abstract}


Qur'an dan non-tradisi intelektual. Artikel ini berusaha untuk membuktikan bahwa pembelajaran ilmiah dapat digunakan sebagai model pembelajaran anti-radikalisme. Mempelajari model ilmiah dimulai dengan mengamati, meminta, mengumpulkan informasi, memproses informasi, dan berkomunikasi. Dengan langkah pembelajaran ilmiah dalam materi Al-Qur'an dan hadits, yang memungkinkan pembelajaran dilakukan dengan menggunakan teori fasilitasi. Siswa dapat mengamati kasus yang terjadi di sekitar mereka dengan mengamati media online dan juga pemahaman Al-Qur'an dan hadits dari berbagai sumber. Tahap pengolahan informasi dapat digunakan sehingga kekuatan kritis siswa terhadap hasil penafsiran Al-Qur'an meningkat. Siswa juga dapat mendiskusikan hasil pengumpulan informasi yang diperoleh dengan teman sebaya mereka dan guru menjadi fasilitator. Kesimpulan yang dapat ditarik dalam penelitian ini adalah bahwa pembelajaran ilmiah dapat digunakan sebagai model belajar Alquran dan Hadis yang memiliki semangat anti-radikalisme.

\section{Keywords \\ Scientific Learning, Qur'anic Learning, Qur'anic Studies}

\section{Pendahuluan}

Problem radikalisme berbasis agama, di Indonesia menjadi problem serius yang memerlukan pemecahan secara tepat dan cepat. Doktrin radikal bukan hanya telah tersebar di kalangan dewasa tetapi sudah merayap secara senyap di lingkungan pelajar. Tahun 2011, Lembaga Kajian Islam dan Perdamaian (LaKIP) merilis hasil survey bahwa 48,9\% siswa di Jakarta menyatakan kesediaan untuk ikut dalam aksi kekerasan yang berkaitan dengan masalah moral atau isu-isu keagamaan sedangkan $63 \%$ di antara bersedia mengikuti penyegelan tempat Ibadah. Pada Tahun 2017, Pusat Pengkajian Islam dan Masyarakat (PPIM), merilis survey bahwa generasi $Z$ (anak yang lahir antara tahun 1995-2005), 37.71\% di antaranya memandang jihad/qital atau perang itu adalah perang melawan non-Muslim. $23.35 \%$ pelajar memandang bom bunuh diri itu bagian dari jihad Islam; 34.03 \% diantaranya sepakat bahwa Muslim yang murtad harus dibunuh; sedang 33,34\% berpendapat bahwa intoleran terhadap minoritas adalah tindakan yang tidak menjadi masalah. Hasil survey ini memperlihatkan bahwa kalangan muda usia pelajar telah banyak yang terpapar radikalisme. Hal ini sangat mengkhawatirkan sebab pelajar adalah masa depan sebuah bangsa.

Muhammad Najib Azca berpendapat remaja yang terpapar radikalisme atau gerakan jihadi akan berlanjut di kemudian hari sebab adanya jaringan dan tidak adanya diskusi kritis (Azca, 2013). Dua hal ini sekiranya mampu menjadi 'pintu masuk' untuk melakukan gerakan untuk menanggulangi faham radikalisme di kalangan pelajar. Azca (2013) juga menjelaskan bahwa istilah-istilah al-Qur'an menjadi alat yang ampuh untuk menanamkan radikalisme. Istilah kafir, thaghut, jihad, Fir'aun dan lain sebagainya yang itu memang terdapat dalam al-Qur'an tetapi dimaknai dengan pemakanaan yang melegalkan kekerasan. Seakan-akan al-Qur'an memperbolehkan tindakan kekerasan kepada orang lain tersebut. Radikalisme selalu mengatasnamakan Allah atas segala kekerasan yang dilakukan (Abdillah, 2014).

Berdasarkan hal tersebut, diasumsikan pintu masuk radikalisme di kalangan pelajar adalah pengenalan istilah-istilah yang terdapat dalam al-Qur'an dengan makna-makna kekerasan. Tulisan ini berupaya menjabarkan bagaimana melawan radikalisme yang telah terlanjur ada di kalangan pelajar melalui pembelajaran kritis terhadap hasil pemakanaan terhadap ayat-ayat al-Qur'an. Dalam sistem pendidikan Indonesia, memandang perlu adanya pendidikan 
agama Islam (PAI) di sekolah menengah tentunya akan mengkaji istilah-istilah al-Qur'an; bahkan di Madarasah Tsanawiyah (MTs) maupun Madrasah Aliyah (MA) terdapat mata pelajar al-Qur'an dan Hadis. Oleh sebab itulah sangat penting untuk mengkenalkan istilah-istilah alQur'an secara kritis sehingga tidak mudah menyematkan istilah-istilah al-Qur'an untuk tujuan kekerasan.

Nilai-nilai kemajemukan dan keberagaman tidak serta merta bisa diterima dengan baik jika tidak dibarengi dengan kesadaran kolektif dari berbagai pihak dan tidak adanya peran serta dari kalangan pendidikan. Pendidikan sudah selayaknya berperan dalam menyelesaikan konflik yang terjadi di masyarakat. Pendidikan harus mampu memberikan tawaran-tawaran yang mencerdaskan, antara lain dengan cara mendesain materi, metode, hingga kurikulum yang mampu menyadarkan masyarakat akan pentingnya sikap saling toleran, menghormati perbedaan suku, agama, ras, etnis dan budaya masyarakat Indonesia yang multikultural. Sudah selayaknya pendidikan berperan sebagai media transformasi sosial budaya dan multikulturalisme.(Muttaqin, 2017)

\section{Metode}

Penelitian ini mempergunakan jenis penelitian library reseach atau studi kepustakaan untuk mencari model pembelajaran al-Qur'an dengan pendekatan scientifik yang memiliki semangat anti radikalisme di Madrasah Aliyah (MA). Pembelajaran al-Qur'an dalam pemahamannya harus memperhatikan ilmu-ilmu al-Qur'an (Study Qur'an) agar pemahamannya tidak terjebak dalam pemahaman radikal. Penelitian library reseach sendiri diartikan sebagai penelitian yang mencari data-data penelitan melalui study kepustakaan. Noeng Muhajir menjelaskan bahwa penelitian kepustakaan sejatinya penelitian yang bersifat teoritis dan filosofis dan tidak mengujinya secara empiris (Muhadjir, 1996).

Pendekatan penelitian yang digunakan adalah pendekatan filosofis yakni kajian yang membahas tentang pengetahuan, nilai, subjek, dan berfikir kritis. Dalam hal ini, penelitian berpusat pada hakekat model pembelajaran al-Qur'an anti-radikalisme. Subyek kajian penelitian ini adalah pembelajaran al-Qur'an anti radikalisme dengan mempergunakan model pembelajaran saintifik.

Data penelitian dibagi menjadi dua yakni data primer dan data sekunder. (a). Data primer adalah data-data materi al-Qur'an anti-radikalisme yang berupa ayat-ayat al-Qur'an, penafsiran al-Qur'an dan berita dari media online. (b). Data sekunder adalah data-data yang berasal dari buku-buku, jurnal atau proseding yang berkaitan dengan subyek penelitian.

Setalah data terkumpul maka data kan dianalisi melalui teknik deskribtif-kwalitatif yakni menggambarkan, menguraikan dan membuat model pembelajaran materi al-Qur'an dengan mempergunakan gambaran kata maupun kalimat. Penelitian ini juga masuk katagori penelitian pengembangan sebab bertujuan membuat rancangan pembelajaran al-Qur'an yang bernuansa anti-radikalisme.

\section{Hasil Penelitian dan Pembahasan \\ Radikalisme Beragama}

Radikalisme dalam KBBI dimanai sebagai paham atau aliran yang menginginkan perubahan atau pembaharuan sosial dan politik dengan cara kekerasan atau drastis; sikap ekstrem dalam aliran politik. Radikalisme agama bisa diartikan sebagai sikap ektrem atau keras dalam beragama. Yusuf Qordowi memaknai radikalisme agama sebagai al-Tatarruf ad-Din atau 
mengambil posisi tarf (pinggir) dalam beragama. Menurutnya sikap mengambil posisi pinggir dalam beragama akan mengakibatkan tiga (3) hal, tidak disukai dalam konteks sikap wajar kemanusiaan; sikap beragama yang temporer (tidak panjang) dan; rentan terjadi pelanggaran terhadap hak orang lain (Qardhawi, 2001). Sehingga, sikap radikal dalam beragam ini memunculkan sikap intoleran yang tidak sesuai dengan asas nilai kemanusiaan.

Sikap tatarrufyang menjadi bibit radikalisme ini, dari sudut pandang sejarah Islam, selalu diasosiasikan dengan gerakan teologi radikal khawarij (Abdullah, 2016), yang merupakan salah faksi teologi-politik pada masa khalifah Ali ibn Abi Thalib (Fadlullah, 2018). Faksi Khawarij terbentuk akibat adanya peristiwa arbitrase atau perjajian damai antara kelompok Ali Ibn Abi Thalib dengan kelompok Mu'awiyah bin Abi Sufyan di perang Shiffin (Hitti, 2005). Perjanjian ini tidak memberi kepuasan kepada sebagian pengikut Khalifah Ali yang kemudian dinamai kelompok khawarij atau orang yang keluar dari barisan pendukung Ali Ibn Abi Thalib.

Faksi khawarij pada awalnya murni dilahirkan dalam peristiwa politik, tetapi pada perkembangannya mereka berfikir dan bertindak secara ektrem (keras) kepada siapa saja secara teologis. Beberapa contoh yang bisa diutarakan dalam pengertian radikalisme adalah sikap takfiri atau mengkafir-kafirkan orang lain yang tidak sepaham dengannya. Pengkafiran ini bermula dari pemikiran bahwa perseteruan Ali dengan Muawayah tidak bisa diselesaikan dengan cara hukum perjanjian antar manusia tetapi harus diselesaikan dengan hukum Allah atau dengan jargon laa hukma illa hukmaAllah yakni melalui al-Qur'an. Lalu, khawarij mensitir ayat al-Qur'an yang menjelaskan bahwa "barang siapa tidak berhukum kepada hukum Allah maka ia adalah kafir" (Qs. Al-Maidah: 44). Pemikiran yang dengan mudah mengkafirkan inilah yang kemudian disebut sebagai pemikiran radikal.

Radikalisme juga tercerminkan dalam sikap dan perbuatan. Khawarij tidak hanya berhenti dalam pemikiran yang mengkafirkan kelompok yang tidak sepaham tetapi juga termanifestasikan dalam perbuatan. Hal ini tercermin dari sikap ektrim dan perilaku keras/kasar dan menganggap halal darah (membunuh), orang yang tidak seide dengannya. Sikap inilah yang disinyalir memicu fitnah, konflik dan kerusakan di muka bumi (Murrad, 2009). Aksi khawarij yang tidak sepaham dengan Ali Ibn Abi Thalib berada pada puncak perbuat dengan majunya Abdullah bin Muljam yang membunuh khalifah Ali ibn Abi Thalib. Ibn Muljam membunuh Ali dengan cara menyerang beliau yang hendak menjalankan salat subuh. Ibn Muljam berhasil melukai secara parah dahi yang membuat Ali ibn Abi Thalib meninggal dunia pada tahun 661 M (Rasyid, 2015).

\section{Pembelajaran Al-Qur'an}

Pembelajaran al-Qur'an merupakan frase umum pendidikan yang terdiri dari dua kata yakni pembelajaran dan al-Qur'an. Pembelajaran berasal dari kata belajar dengan penambahan 'pem-' dan “-an”. Penambahan tersebut menunjukkan sebuah proses tentang aktifitas belajar. Para ahli mendefinisikan terma 'pembelajaran' dengan definisi yang berbeda-beda; pembelajaran dimaknai sebagai setiap upaya sengaja dan sistematis yang dilakukan oleh seorang pendidik dengan mengondisikan peserta didik untuk melakukan kegiatan mengajar (Sudjana, 2001). Dari sudut pandang strategi, pembelajaran diartikan sebagai upaya untuk membelajarkan siswa (Muhaimin \& Ali, 1996). Sedangkan dari sudut pandang kurikulum, pembelajaran diartikan sebagai suatu kombinasi yang tersusun yang meliputi unsure-unsur manusiawi, material, fasilitas, perlengkapan, dan prosedur yang saling mempengaruhi mencapai tujuan pembelajaran (Hamalik, 1995). Pembelajaran secara administratif diatur dalam UU Sisdiknas Tahun 2003 
yang didefinisikan sebagai proses interaksi peserta didik dengan pendidik dan sumber belajar pada suatu lingkungan belajar (Sisdiknas, 2003).

Sedangkan al-Qur’an, para ahli mendefinisikannya sebagai firman Allah yang termasuk mukjizat, diberikan kepada Nabi Muhammad ; ditulis dalam bentuk mushaf dan diriwayatkan secara mutawatir dan membacanya dihitung sebagai ibadah (aș-Ṣālị̣, 2005). Al-Qaththan menyebutkan nama-nama al-Qur'an sebagai berikut al-Qur'an (bacaan), al-Kitab (kitab Suci), al-Furqon (pembeda), adz-Dzikr (Pengingat), dan at-Tanzil (yang diturunkan) (Al Qaththan, 2018). Sifat al-Qur'an digambarkan sebagai berikut yakni sebagai nur cahaya bagi manusia (Qs. An-Nisaa, 174); sebagai nasehat dari Allah, obat penawar penyakit, petunjuk bagi manusia (Qs. Yunus: 57); pembawa kabar gembira dan peringatan (Qs. Fussilat 3-4); al-Qur'an yang tersohor (Qs. Al-Buruj: 21), kitab yang mulia (Qs. Fusilat: 41), kitab yang diberkati (Qs. Al-An'am: 92) dan lain sebagainya.

Jadi pembelajaran al-Qur'an adalah interaksi antara pendidik dan murid guna mempelajari kitab suci, firman-firman Allah yang memiliki sifat yang agung dan nama-nama julukan yang tersohor. Dalam PMA RI 000912 Tahun 2013 tentang Kurikulum Madrasah 2013 Mata Pelajaran Pendidikan Agama Islam dan Bahasa Arab, Mata Pelajaran Al Quran Hadis dipandang sebagai sumber utama ajaran Islam, keduanya dipandang sebagai sumber aqidahakhlak, fikih baik ibadah muapun muamalah. Sehingga mata pelajaran al-Qur'an Hadis ini berada di setiap unsur mata pelajaran agama Islam. Subtansi mata pelajaran ini memberi mmotivasi kepada peserta didik untuk mencintai kitab suci, mepelajari dan mempraktekkan ajaran agama Islam sekaligus menjadikannya sebagai pedoman kehdupan sehari-hari (Nomor, 2013). Ruang lingkup pembelajaran al-Qur'an dan Hadis meliputi:

1. Membaca dan menulis yang merupakan unsur penerapan ilmu tajwid

2. Menerjemahkan makna (tafsiran) yang merupakan pemahaman, interpretasi ayat dan hadi dalam memperkaya khazanah intelektual.

3. Menerapkan isi kandungan ayat/ hadis yang merupakan unsur pengamalan nyata dalam kehidupan sehari-hari.

Secara subtantial, PMA RI 000912 Tahun 2013 juga mengatur tujuan pembelajaran alQur'an yang meliputi:

1. Meningkatkan kecintaan peserta didik terhadap al-Qur'an dan Hadis.

2. Membekali peserta didik dengan dalil-dalil yang terdapat dalam al-Qur'an dan Hadis sebagai pedoman dalam menyikapi dan menghadapi kehidupan;

3. Meningkatkan pemahaman dan pengamalan isi kandungan al-Qur'an dan hadis yang dilandasi oleh dasar-dasar keilmuan tentang al-Qur'an dan hadis.

\section{Dasar-dasar Penafsiran dalam Pembelajaran al-Qur'an}

Sudah disebutkan dalam ruang lingkup pembelajaran al-Qur'an di Sekolah Menengah bahwa ada upaya untuk memahami dan menafsirkan ayat al-Qur'an. Aktifitas menafsirkan memang tidaklah mudah. Banyak larangan untuk kegiatan tersebut. Ibn Katsir menyatakan barang siapa menafsirkan al-Qur'an dengan logika/pikiran/nafsunya maka hukumnya haram (Katsir, 2003). Pernyataan ibn katsir tersebut menemukan momentumnya apabila keliru memahami ayat-ayat suci la-Qur'an maka ia akan memegang, mempercayai dan mengamalkan sesuatu yang salah. Ia merasa mengamalkan al-Qur'an padahal pemahamannya terhadap ayatayat al-Qur'an tidaklah benar. Oleh sebab itulah, kesalahan memahami ayat-ayat al-Qur'an ini 
akan mengantarkan sikap-sikap intoleran dan memunculkan benih-benih radikalisme dalam beragama. Munculnya keberagaman dalam memahami makna yang terkandung dalam al-Qur'an menjadi salah satu bentuk mengurangi fanatisme tafsir dan sebagai perbandingan pemaknaan. Sehingga benih-benih radikalisme dalam beragama juga bisa dikurangi (Jonwari, 2013).

Dalam konteks untuk menghindari munculnya benih-benih radikalisme dalam beragama di kalangan siswa, pembelajaran al-Qur'an pada mata pelajaran PAI ini harus didasarkan kepada beberapa hal yakni ;

1. Teori-teori Penafsiran

Teori penafsiran al-Qur'an telah dikembangkan oleh para sarjana Muslim. Keberadaan terori penafsiran al-Qur'an ini telah sampai pada tahap mendekati sempurna. As-suyuti dalam Al-Itqon menyatakan secara hiperbolis bahwa ilmu-ilmu al-Qur'an ini sudah nadhizat (masak) dan ihtaroqot (gosong) (Suyuti, 1948). Artinya, teori-teori al-Qur'an untuk membantu proses pemahaman al-Qur'an ini telah cukup mempermudah medapatkan makna yang benar dalam ayat-ayat al-Qur'an. Teori-teori penafsiran al-Qur'an ini merupakan alat bantu dalam menafsirakan al-Qur'an. alat bantu inilah yang sering disebut sebagai ulumul qur'an. Ruang lingkup kajian ulumul qur'an dijelaskan oleh az-Zarkani sebagai Pembahasan dan kajian masalah yang berhubungan dengan al-qur'an, dari segi turunnya, urut-urutannya, pengumpulannya, penulisannya, bacaannya, mukjizatnya, nasikh mansukhnya, dan bantahan terhadap hal-hal yang dapat menimbulkan keragu-raguan terhadap al-qur'an dan sebagainya (Az-Zarqani, 2001).

Teori penafsiran al-Qur'an salah satunya hal yang perlu disadari tentang kesadaran kesejarahan atau waktu (tempus). Dikutib oleh as-Suyuty dalam al-Itqon, ibn Taimiyyah menjelaskan bahwa 'mengetahui sebab-sebab turunnya al-Qur'an adalah metoda atau cara yang paling mudah untuk memahami al-Qur'an’ (Suyuti, 1948). Imam Syatibi dalam kitab alMuwafaqot juga memperingatkan keras pemahaman al-Qur'an yang terfokus pada teksnya saja; tanpa melihat koneteks asbab nuzul turunnya ayat al-Qur'an; peristiwa yang melatar belakangi penurunan ayat merupakan komponen dasar dalam proses pemahaman al-Qur'an (Al-Shatibi, 2006).

Di samping kesejarahan yang berkaitan dengan waktu, juga perlu disadari soal lokasi (locus) penurunan al-Qur'an. Dalam kajian Ulumul Qur'an, kajian yang menyoal di mana ayatayat al-Qur'an ini diturunkan dikenal dengan sebutan makiyyah dan madaniyah. Lebih dari itu, pemetaan makiyyah dan madaniyah juga dipahami sebagai perubahan pola dakwah nabi; dari fase indzar ke fase risalah. Para ulama sepakat bahwa fase indzar (memberi peringatan) adalah ayat-ayat makiyyah di mana Muhammad diberi tugas untuk memberi peringatan bukan membuat sebuah hukum kemasyarakatan. Nasr Hamid Abu Zaed memahami ayat-ayat makiyyah atau fase indzar sebagai bagian dari taraf kognitif yang terjadi perubahan konsep ketuhanan lama (pagan, politeis) pada konsep ketuhanan baru (monotheis). Fase indzar memberikan pemahaman dengan menggerakkan kesadaran bawa tengah terjadi kerusakan dalam realitas kehidaupan masyarakat (Zaid, 2002); sehingga perlu perubahan radikal yang diawali dengan konsep ketuhanan yang monoteis.

Sedangkan fase risalah atau madaniyyah adalah fase di mana ayat-ayat al-Qur'an turun berkaitan dengan bagaimana membentuk masyarakat yang adil makmur sentausa. Fase ini berawal secara nyata pada saat Nabi Muhammad setelah pulang dari habasyah, menemui utusan yatsrib (Madinah) dan beliau dibaiat akan dibela istri dan anak-anaknya begitu pula sahabat nabi yang mengkutinya. Peristiwa ini menandai perubahan sifat ayat-ayat al-Qur'an yang diturunkan 
kepada nabi Muhammad dari indzar (peringatan) kepada risalah guna pembangunan peradaban Islam yang lebih baik, tata aturan, hukum dan lain sebagainya.

2. Filsafat Penafsiran

Pada dasarnya, penafsiran bukanlah masalah metode tetapi masalah dialektika. Kalau kita memahami ayat-ayat al-Qur'an dengan metode yang (dianggap) tepat maka apakah kita telah berhasil menemukan kebenaran? Lalu, kenapa seseorang ketika memahami ayat-ayat al-Qur'an dengat metode yang sama-sama tepat tetapi menghasilkan pemahaman yang berbeda? Pertanyaan dasar inilah yang kemudian memberi pemahaman bahwa sebenarnya proses penafsiran bukanlah masalah metode tetapi masalah dialektika antara eksistensi mufassir dengan ayat suci al-Qur'an.

Menurut Gadamer, dalam proses memahami akan selalu didahului dengan prapemahaman sanga pembaca dan keinginan berpartisipasi dengan makna teks al-Qur'an; horizon pemahaman pembaca sangat mempengaruhi makna yang dihasilkan dari proses memahami teks kitab suci. Oleh sebab itulah sebenarnya, ketika seseorang memahami kitab suci, manusia masuk pada pemahaman yang terkondisikan dengan realitas sejarah penafsir yang selalu berada dalam ruang dan waktu. Secara teknis, keadaan ini disebut Gadamer yang dikutip Palmer sebagai effective historical consciousness (Palmer, 1969). Karena eksistensi diri sangat mempengaruhi aktifitas penafsiran maka penafsir seringkali terjebak pada dua (2) kondisi, pertama, terlalu mereduksi makna dan memasukkan konsep diri secara berlebihan sehingga sikap reduktif ini mengakibatkan hilangnya kekhasan makna teks. Kedua, sikap self-effacement ketika kita menafikan kepentingan kita sendiri dengan berusaha masuk ke dalam kacamata orang lain.

3. Pandangan Kritis Penafsiran al-Qur'an

Al-Qur'an merupakan kitab suci keagamaan yang memmpunyai pengaruh bagi manusia khususnya orang muslim. Padangan kritis terhadap penafsiran al-Qur'an berasal dari pemahaman bahwa aktifitas penafsiran itu dipengaruhi faktor ekternal teks seperti ideologi dan kepentingan penafsir. Aktifitas penafsiran bukan hanya aktifitas pemahaamana an sich tetapi juga merupakan aktifitas yang menjadi media dominasi dan kekusaan. Sehingga, hasil pemahaman terhadap teks itu perlu dicurigai sebab bukanlah hasil yang netral. Horizon pemahaman dipengaruhi oleh kepentingan sosial (social interest) dan kepentingan kekuasaan (power interest).

Dalam sebuah hadis yang diriwayatkan oleh Tirmidzi rasulullah bersabda,

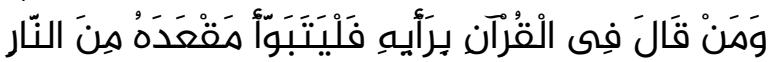

“Barangsiapa berkata tentang Al Qur'an dengan logikanya (semata), maka silakan ia mengambil tempat duduknya di neraka"

Dari hadis tersebut menyatakan larangan keras untuk mempergunakan ayat-ayat alQur'an untuk kepentingan sosial maupun kepentingan kekuasaannya. Para pelaku yang menafsirkan dengan kepentingannya tersebut maka akan dipastikan diganjar oleh Allah neraka sebagai tempatnya. Ibn Katsir dalam kitab tafsirnya menyerukan untuk selalu berhati-hati menafsirakan al-Qur'an sebab al-Qur'an merupakan kalamullah atau firman Allah (Katsir, 2003).

Pembelajaran al-Qur'an dengan Pendekatan Scientifik

dalam Kasus Bom Bunuh Diri di Gereja Surabaya

Pada tahun 2018, media online mengabarkan adanya bom bunuh diri di tiga gereja yaitu, Gereja Santa maria Tak Bercela Ngagel Madya, Gereja Kristen Indonesia Jalan Diponegoro dan 
Gereja Pantekosa Pusat Surabaya Jalan Arjuna dengan selang 30 menit bom meledak (13/05/2018) dan terjadi kembali pukul 08.50 WIB di Polrestabes Surabaya. Pelaku serangan bom di beberapa tempat tersebut dilakukan satu keluarga yang salah satunya anak-anak berusia 10 tahun sebagai pelaku bom bunuh diri yang statusnya pelajar.

Kalau dilihat dari kasus tersebut ada tiga hal yang menjadi bahasan yakni jihad, nonmuslim dan pemerintahan thaghut. Dalam Qs. At-Tahrim (66): 9 disebutkan Allah berfirman "Hai Nabi, perangilah orang-orang kafir dan orang-orang munafik dan bersikap keraslah terhadap mereka. Tempat mereka adalah jahannam dan itu adalah seburuk-buruknya tempat kembali."

Dalam ayat tersebut memang dinyatakan bahwa Nabi disuruh untuk bersikap keras dan berjihad kepada orang-oarang kafir dan munafik. Kata jahidu dalam ayat tersebut dimaknai sebagai bom bunuh diri dan kata kuffar dipahami bahwa semua non-muslim dan orang-orang yang berbeda ideologi dengan mereka sesat dan wajib dibunuh.

Dari kasus tersebut, bagaiamana menjelaskan kepada peserta didik agar pemahaman ayat tersebut tidak terjebak kepada radikalisme pemahaman yang menghasilkan perbuatan kekerasan ekstrem. Pendidik harus mampu merumuskan pendektan yang bagus untuk menjelaskan dua kasaus yang berbeda; kasus tentang realitas teks al-Qur'an dan di sisi lain realitas bom di gereja Surabaya. Salah satu pendekatan yang dipakai adalah pendektan scientifik. Penerapan pendekatan saintifik dalam pembelajaran melibatkan keterampilan proses seperti mengamati, mengklasifikasi, mengukur, meramalkan, menjelaskan, dan menyimpulkan.

Adapun langkah-langkah pendekatan pembelajaran scientfifik dalam konteks pemahaman Qs. At-Tahrim:9 sebagai berikut.

\section{Mengamati (observasi)}

Kebermaknaan proses pembelajaran (meaningfull learning) menjadi tujuan dari aktifitas mengamati. Untuk itulah pengajar harus mampu menjadikan ayat tersebut sebagai ayat yang sangat bermakna dengan cara mengamati. Pengamatan bisa dilakukan dengan membaca berulang-ulang teks al-Qur'an dan memberikan penekanan kepada keyword atau mufradhat yang penting yakni jahidi, al-kuffar, al-munafiqin dan waghlud 'alaihim. Lalu berilah contoh pengamatan sekitar kegiatan bom bunuh diri di geraja-geraja merupakan bagian pengamalan ayat untuk bersikap keras kepada non-muslim.

2. Menanya

Menanya atau bertanya dilakukan dengan cara mengajukan pertanyaan tentang informasi yang tidak dipahami dari apa yang diamati atau pertanyaan untuk mendapatkan informasi tambahan tentang apa yang diamati. Apa itu jihad? Apa itu kafir? Siapa orang kafir? Apa itu munafik? Siapakah orang munafik? Apakah bom bunuh diri di gereja merupakan jihad? Pertanyaan-pertanyaan menjadi penting dilontarkan siswa agar aktif dan memberi inspirasi untuk mengembangkan pertanyaan dari atau untuk dirinya. Dengan seperti itu diharapkan siswa juga memiliki soft skill untuk bertanya dan mempertanyakan fenomena di lingkungan sekitarnya. 3. Mengumpulkan informasi

Siswa diajak mengumpulkan informasi terkait dengan pemaknaan kafir, jihad, munafik dan kasus bom bunuh diri di gereja Surabaya. Sekarang ini mengumpulkan informasi sangat musdah dengan dibantu search engine di internet sehingga mempermudah dan mempercepat proses pengumpulan informasi yang berkaitan dengan istilah-istilah kunci dalam Qs. AtTahrim:9. 
4. Mengasosiasikan/mengolah informasi atau menalar

Setelah mendapatkan informasi terkait dengan pemahaman konsep-konsep kunci dalam ayat, lalu pengajar mengajukan pertanyaa terkait apakah bom bunuh diri yang dilakukan di Surabaya itu adalah wujud pengamalanan Qs. At-Tahrim:9 tersebut. Dalam sesi ini siswa akan dilatih untuk menalar informasi konseptual yang sudah didapatkan tentang jihad, bersikap keras, kuffar dan munafik dengan informasi tentang bom bunuh diri di gereja. Tentunya, pengajar juga harus memperhatikan kerangka konseptual pemahaman

5. Mengkomunikasikan

Kegiatan mengkomunikasikan dapat dilakukan melalui menuliskan atau menceritakan apa yang ditemukan dalam kegiatan mencari informasi, mengasosiasikan, dan menemukan pola. Pada kasus pembelajaran Qs. At-Tahrim:9 ini siswa diberi kesempatan untuk menceritakan pola antara penafsiran tentang maksud firman Allah tentang perintah berjihad dan bersikap keras kepada kafir dan munafiq.

\section{Kesimpulan}

Dari kajian tentang pembelajaran al-Qur'an anti radikalisme dapat disimpulkan bahwa (1) Pendidikan anti radikalisme dapat dimulai melalui pembelajaran al-Qur'an sebab al-Qur'an adalah sumber dari perundang-undangan, tata nilai dan etika. tetapi guru harus mempertimbangkan tiga (3) hal yang terkait dengan dasar-dasar penafsiran yakni (1) teori penafsiran al-Qur'an atau ulumul qur'an. Dalam kajian ini seorang guru dapat memahami bagaiman teknis metode menafsirkan al-Qur'an baik informasi tentang kesejarahan (tempus) maupun lokasi penurunan al-Qur'an (locus). (2) filasafat penafsiran atau pemahaman di mana seorang ketika memahami akan membawa horizon eksitensial pribadinya. Sehingga apabila ada keberbedaan maka harus saling menghormati. (3). Penafsiran kritis; artinya adanya kesadaran bahwa orang yang mempergunakan untuk kepentingan sosial dan kepentingan kekuasaan. Oleh sebab itulah, Allah akan menghukum orang yang menafsirkan al-Qura dengan logika kepentingan dirinya. (2) Pendidik juga harus mampu meramu pendekatan pembelajaran alQur'an dengan sebaik mungkin salah satunya adalah pendekatan scietifik dengan studi kasus. Siswa harus diberi pengalaman bukan hanya pengalaman yang bersifat tekstual tetapi kontekstual seperti memahami Qs. At-Tahrim:9 dengan studi kasus bom bunuh diri di gereja Surabaya.

\section{DAFTAR PUSTAKA}

Al-Qardhawi, Yusuf, (2001). Al-Sahwah al-Islamiyyah Baina-al-Juhud wa al-Tarruf, Kairo: Bank al-Taqwa

Abdillah, J. (2014). Radikalisme Agama: Dekonstruksi Tafsir Ayat-Ayat "Kekerasan” Dalam AlQur'an. KALAM, 8(2), 281-300.

Abdullah, A. (2016). Gerakan Radikalisme dalam Islam: Perspektif Historis. Addin, 10(1), 128.

Al-Shatibi. (2006). al-Muwafaqat. Dar Al-Hadith.

Al Qaththan, S. M. (2018). Pengantar Studi Ilmu Al Quran. Pustaka Al-Kautsar. aș-Ṣāliḥ, Șubḥī. (2005). Mabāhị̂ fì 'ulūm al-Qur'ān. Dār al-'Ilm lìl-Malāyīn.

Az-Zarqani, M. A. A. (2001). Manahil al-'Irfan. Beirut: Dâar Al Fikr, Tt. 
Azca, M. N. (2013). Yang Muda, Yang Radikal: Refleksi Sosiologis Terhadap Fenomena Radikalisme Kaum Muda Muslim di Indonesia Pasca Orde Baru. Jurnal Maarif, 8(1), 1444.

Creswell, J. (2015). Riset pendidikan: Perencanaan, pelaksanaan, dan evaluasi riset kualitatif \& kuantitatif. Yogyakarta: Pustaka Pelajar.

Fadlullah, M. E. (2018). Ahlu al-Sunnah wa al-Jamaah dalam Perspektif Said Aqil Siradj. Nidhomul Haq: Jurnal Manajemen Pendidikan Islam, 3(1), 33-43.

Hamalik, D. O. (1995). Kurikulum dan pembelajaran. Bumi Aksara.

Hitti, P. K. (2005). History of the Arabs: Rujukan induk dan paling otoritatif tentang sejarah peradaban Islam. Penerbit Serambi.

Jonwari, J. (2013). Nilai-Nilai Pluralisme dalam Ajaran Sosial Islam: Perspektif Fikih Realitas. Lisan al-Hal: Jurnal Pengembangan Pemikiran Dan Kebudayaan, 7(1), 53-75.

Katsir, I. (2003). Tafsir Ibnu Katsir Jilid 1-7. Beirut Lebanon: Daar Ma'rifah.

Muhadjir, N. (1996). Metodologi penelitian kualitatif: pendekatan positivistik, rasionalistik, phenomenologik, dan realisme metaphisik telaah studi teks dan penelitian agama. Rake Sarasin.

Muhaimin, A. G., \& Ali, N. (1996). Strategi belajar mengajar. Surabaya: Karya Anak Bangsa.

Murrad, M. (2009). Kisah Hidup Ali Ibn Abi Thalib. Serambi Ilmu Semesta.

Muttaqin, A. I. (2017). Nilai-Nilai Pendidikan Multikultural Dalam Al Quran. AL-WIJDÁN: Journal of Islamic Education Studies, 2(2), 69-77.

Nomor, P. M. A. R. I. (2013). 000912 Tahun 2013. Tentang Kurikulum Madrasah.

Palmer, R. E. (1969). Hermeneutics. Northwestern University Press.

Rasyid, S. (2015). Kontroversi Sekitar Kekhalifaan Ali Bin Abi Thalib. Rihlah Jurnal Sejarah Dan Kebudayaan, 2(01), 13-20.

Sisdiknas, U.-U. (2003). UU RI No. 20 Tahun 2003. Jakarta: Sinar Grafika.

Sudjana, D. (2001). Metode dan teknik pembelajaran partisipatif. Falah Production.

Sugiyono, H. (2016). Metode kualitatif dan kuantitatif. Cetakan Ke-23. Alfabeta, Bandung.

Suyuti, M. I. A.-T. (1948). Al-Itqan Fi Ulum Al-Qur'an. Beirut: Dar al-Fikr

Zaid, N. H. A. (2002). Tekstualitas Al-Qur'an; Kritik terhadap Ulumul Qur'an. LKIS Pelangi Aksara. 